\title{
UNDERLYING INDICATORS FOR MEASURING SMARTNESS OF BUILDINGS IN THE CONSTRUCTION INDUSTRY
}

\begin{abstract}
Purpose: The introduction of the Smart Buildings Technology (SBT) concept (which incorporates elements of the Zero Energy Buildings (NZEB) concept) could be a measure in ensuring efficient energy consumption and high performance in buildings. Smart buildings provide solutions to improve building efficiency, and reduce energy consumption, carbon emissions and concomitant energy costs. In order to adopt SBT in the construction industry, it is important to identify the indicators of smartness of buildings, even though such may differ from region to region or even country to country. However, there have been inefficient studies identifying the indicators of smartness of buildings, especially in developing countries such as Ghana. This study investigates the underlying indicators for measuring the smartness of buildings in the construction industry.
\end{abstract}

Methodology: An overarching post-positivist and empirical epistemological design was adopted for this research to analyse primary quantitative data. Data was collected via a structured questionnaire survey with 227 respondents including project managers and construction design teams in Ghana. The mean ranking analysis and one sample t-test were employed to analyse the data.

Findings: Research findings revealed that the level of knowledge of smart building indicators is averagely high in the Ghanaian construction industry. With regards to the indicators of smart building, 'sensors implementation to manage light level, air quality, temperature, fire alarm and smoke detector' is regards as the most significant measure of smart buildings in the Ghanaian construction industry. Also, 'remote implementation monitors building conditions and occupancy', 'implementation of any software that can talk to legacy equipment from many different manufactures' and 'data analytic' are statistically insignificant in measuring smartness of buildings.

Practical Implication: Practically, policy makers and practitioners can use the study's results as blueprint guidance to appreciate and utilise the idea of smartness of buildings because it can improve building performance therefore, promoting the adoption of SBTs. To the body of knowledge, this study has identified the significant indicators for measuring the smartness of buildings, which can further influence SBTs adoption.

Originality: Using the results, a model consisting of significant indicators for measuring building smartness was developed to help improve building performance.

Recommendation: The study recommends future research to evaluate the awareness level of Smart Building Technologies (SBTs) by construction professionals and identify barriers to its adoption.

Keyword: Building performance, construction industry, developing countries, energy efficiency, indicators, smart building technology.

\section{Introduction}

Buildings account for approximately 30-40\% of global energy demand and humans invest almost their entire lives (circa $80-90 \%$ of the time) in buildings, so reducing energy demand through efficient activity is the subject of construction control research (Park and Nagy, 2018). Buildings also impact upon the environment in a form of water and air-pollution due 
to for example, cement usage (Raffetti et al., 2018). Wang et al. (2019(Urge-Vorsatz et al., 2013; Santamouris, 2016; Ürge-Vorsatz et al., 2018).) opined that present actions are insufficient and suggested that resolute and timely effects are needed on a global scale to minimize the harmful impact of anthropogenic activities on the environment. Sustainable development is needed to help minimize the building's negative impact on the environment using an integration of efficient methods based on multidisciplinary knowledge (Baleta et al., 2019).

With regards to rapid global industrialisation and urban development, preventive actions are needed to prevent ripple effects that could cause serious environmental sustainability issues; therefore, the argument for smart and efficient management is compelling (Ilankoon et al., 2018; Nižetić et al., 2019). According to the Energy Performance of Buildings Directive (EPBD), newly constructed buildings in the European Union (EU) need to be NetZero Energy Building (NZEB) (which is an integrated part in a smart building (Karlessi et al., 2017)) by the end of 2020 (European Union, 2014). Buckman et al. (2014) proffered that smart buildings are the future of the urban built environment, demanding more functionality from more constrained resources and more stringent building regulations. The smart home concept emanated from the notion of home automation, which provides benefits to end-users including lower energy costs, provision of comfort and security, and assistant to everyone including the disabled (Pedrasa, 2010). The advent of the Smart Buildings Technology (SBT) concept, which also constitutes elements of the NZEB concept (Harkouss et al., 2018), could be a preventive measure in ensuring efficient energy consumption in buildings (Nižetić et al., 2019). Smart building indicators facilitate the rating of the smart readiness of buildings i.e., expand the capability to adapt operations to occupant needs, optimize energy efficiency and overall performance, and adapt building operations in reaction to signals from the energy grid. Smart building indicators are capable of raising awareness amongst occupants and construction professionals of the inherent value behind building automation and electronic monitoring of technical building systems - this simultaneously augments occupants' confidence about actual savings of new enhanced functionalities (VITO NV, 2018). However, there are no particular recommendations on how advanced technologies should be applied to achieve the smart building concept. It is therefore important to identify what indicators would be most critical in measuring a building's smartness (Apanaviciene et al., 2020).

In developing countries, the number of new building developments is growing rapidly and the energy prices and market often do not encourage the use of efficient technologies (Hui, 2000; Iwaro and Mwasha, 2010). Buildings and human activities within contribute to a major share of global environmental concerns (Urge-Vorsatz et al., 2013; Santamouris, 2016; ÜrgeVorsatz et al., 2018). Ghana is of no exception, especially in respect of its energy challenges. According to Koranteng and Mahdavi (2011), energy requirements for cooling of office buildings in Ghana represent a growing burden for both the environment and the economy. The Energy Commission Ghana (2009) reported that energy consumption of households increased from $26 \%$ (of total national energy consumption) in 2000 to $37 \%$ in 2005 . Few researchers have encouraged smart buildings in Ghana, in the context of energy efficiency (cf. Koranteng 2010; Koranteng and Mahdavi, 2011; Addy et al., 2014; Addy et al., 2017; Sarfo, 2016; Gyamfi, 2018; Chan et al., 2018; and Ahiabor, 2019). In order to adopt the smart building model, it is important to identify the indicators of a building's smartness, even though it may differ from region to region or country to country. However, there appear to be inefficient studies identifying the indicators of smartness of buildings, especially in developing countries such as Ghana. The paucity of conclusive evidence on SBT adoption in the Ghanaian construction industry is largely attributed to low level of awareness and 
cognisance about smart building concept amongst the construction team players or professionals as a whole (Makarfi, 2015). This study, therefore, fills this knowledge gap by investigating the underlying indicators for measuring the smartness of buildings in the construction industry by involving the construction professionals, especially the design team. The ambition being to produce blueprint guidance that can assist policy makers and government officials make more informed decisions in future planning of the built environment.

\section{The Concept of Smart Buildings}

The smart building concept uses smart technology (such as those adopted under industry 4.0 (cf. Newman et al., 2020)) to reduce energy consumption and improve comfort and users' satisfaction (Attoue et al., 2018). Smart buildings can be many things but are simply defined as: using building technology systems to optimise building services and operation for the betterment of its occupants and management (Vattano, 2014). Smart building is generally referred to a building with an integrated services platform for the intelligent management of energy facilities, monitoring of consumption, adoption of security systems and video surveillance (ibid). Balta-Ozkan et al. (2014) also added to knowledge by defining smart building as a residence equipped with a communications network, linking sensors, domestic appliances and devices that can be remotely monitored, accessed or controlled, and provides services that respond to inhabitants' needs. Smart buildings are developed upon intelligent building concepts, as briefly explained by Agarwal et al. (2010). Smart buildings contain aspects of automation (Edwards et al., 2017), and similarly, intelligence is an important aspect of smart buildings (Wang et al., 2012; Shaikh et al., 2014). Building automation requires "a lot of 'intelligent' devices" (Runde and Fay, 2011) and smart buildings are increasingly using a number of smart devices, materials and sensors (Arkin and Paciuk, 1997; Wong et al., 2008; Gilder and Clements-Croome, 2010).

McGlinn et al. (2010) proffered smart buildings as "a subset of smart environments" where smart environments are "able to acquire and apply knowledge about the environment and its inhabitants in order to improve their experience in that environment." Sinopoli (2010) argued that a smart building should focus primarily on the integration of the building's systems and the processes by which the building is designed and implemented. Building automation is key to making buildings more operationally efficient, and also to the integration of buildings with smart grids (Gungor et al., 2011) and other external applications such as cloud computing. Smart buildings incorporate and account for knowledge, industry, power, materials and construction as a whole building system, with adaptability at the heart to meet building progress drivers viz: energy and efficiency, durability, and comfort and satisfaction (Buckman et al., 2014). The concept of smart building must be integrated into all stages of the building's life cycle, focusing on the design, construction and operational phases. Therefore, in many cases, smart buildings combine the features of both a sustainable and a green building. In summary, smart buildings serve human inhabitants, providing them with more rational and personalised solutions, making their lives easier in terms of economic, environment, social and cultural aspects. This study underscores the inextricable concept of smart buildings in upholding the building performances and how this can help the construction industry attain sustainability.

\section{Theory of Intelligent Design}


According to Witt (2007), the theory of intelligent design (ID) holds that certain features of the universe and of living things are best explained by an intelligent cause vis-à-vis an undirected process such as natural selection. In a broader sense, ID is simply design detection (that is, how to recognize patterns arranged by an intelligent cause for a purpose). "Understanding the concept of intelligent design and also realising that science is provisional and is subjective to many influencing parameters, we branch out from this point into the world of Architectural Design and understand the disparity pronounced in the design created against that of nature" (Gilder and Clements-Croome, 2010). Gilder and Clements-Croome (ibid) assert that, the concept of engineering a building has been made as human sensitive and responsive with prevalent technology and systems. Therefore, a building can be viewed as living organism that harbours its resident from the external climate. This then depends on systems such as building automation system (BAS), embedded sensors and actuators, design quality indicator (DQI) results, etc.

Lastly, this current study also relates to the theory of ID. With the advent of technology, buildings are increasingly responsive to human needs such that devices (automation/sensory based) are easier to use and function but also afford contemporary architecture an image of sophistication and high-tech look. According to Gilder and Clements-Croome (ibid), even though the complexity and intelligent nature of smart buildings evolves from an intelligent cause, it is also envisioned with systems illustrated in Figure 1.

\section{Building Automation Systems (BAS)}

"Building automation system constitutes the use of web-enabled devices which allows remote building control and monitoring by interaction of the central BAS work station with the remote dialup system through modem".

\section{Sensors and Actuators}

"Wireless information is given to the BAS using the embedded sensors and actuators about the user occupancy, heating and ventilation, security, etc".
3. Integrating Structure and HVAC (Heating, Ventilation and Air Conditioning)

"Computer vision system allows counting the number of residents within an air-conditioned space and informs the control system of the distribution of the residents. Internet-based HVAC system allows authorized user to keep close contact with the BAS, where the user is".

\section{Quality Indicator (DQI) results}

"The DQI brings out the means to assess the buildings current design should be further looked and researched into".

Figure 1: Systems of Intelligent Design (ID) Theory for Smart Building (Author's

Construct, 2020)

\section{Dimensions of Accreditation of Smart Buildings}


In the last decade, the focus of building research has slowly shifted from sustainable building to smart intelligent building, and both concepts are expected to merge in order to cater to the growing requirement for a better, productive and efficient environment. Such an environment would comprise of functionality; safety-security; thermal, acoustical, indoor air quality; visual comfort; and building integrity without consuming excessive energy (Das, 2012). A smart building is a building with changeable features that can respond with minimum human interference to change the external and internal environment for the occupants' benefit and comfort, taking into consideration the financial perspective and reduction in energy use (Hume, 2013). A smart building should have the ability to integrate automated building controls and optimise operations to lowering both cost and energy usage compared to the conventional or traditional buildings (Hume, 2013; Indrawati et al., 2017). SBTs are capable of improving indoor climate conditions and simultaneously empower building occupants by providing information on energy use and indoor climate change (Wouters and Laustsen, 2018).

According to Indrawati et al. (2017), "smart building is termed as the collaboration of telecommunications, building automation, system integration and office automation for optimizing economic, efficiency, comfortability, functionality and stability of smart building." It is therefore, logical to complement the indicator of the building's energy performance, as reflected by an Energy Performance Certificate, with an indicator of the smartness of a building (Wouters and Laustsen, 2018). Buckman et al. (2014) opined that "the dimension of a smart is adaptability, control, enterprise, material and construction." Smart cities start with smart buildings (2016) also identified seven dimensions of smart buildings including "instrument and control, connectivity, interoperability, security and privacy, data management, computing resources and analytics." From extensive research undertaken by Honeywell (2014), safe, green, comfort and productivity were considered as dimensions and indicators of smart building. Supratman (2016) also supported with research by including "building energy management, atomization by using Information Communication Technology (ICT), and green building construction as the dimensions of smart building." Table 1 provides a summary of the smart building dimensions with the indicators.

Table 1: Smart Building Indicator (SBTs)

\begin{tabular}{lll}
\hline Dimensions & Indicators & References \\
\hline Building Control system & $\begin{array}{l}\text { 1. Remote implementation monitors building } \\
\text { conditions and occupancy. } \\
\text { 2. Real time monitoring. } \\
\text { 3. Implementation of any software that can talk } \\
\text { to legacy equipment from many different } \\
\text { manufactures. }\end{array}$ & $\begin{array}{l}\text { Buckman et al. (2014), Frost and Sullivan } \\
\text { (2009), Optergy (2019), Supratman (2016) }\end{array}$ \\
& $\begin{array}{ll}\text { 1. Implementation of power consumption } \\
\text { monitoring and control. }\end{array}$ & $\begin{array}{l}\text { Frost and Sullivan (2009), Honeywell } \\
\text { (2014), Optergy (2019) }\end{array}$ \\
\hline Energy Management & $\begin{array}{l}\text { 2. Implementation of energy efficient electrical } \\
\text { appliance. }\end{array}$ & \\
& 3. Implementation of backup energy & \\
& $\begin{array}{l}\text { Sensors implementation to manage light level, } \\
\text { air quality, temperature, fire alarm and smoke }\end{array}$ & $\begin{array}{l}\text { Buckman et al. (2014), Frost and Sullivan } \\
\text { (2009), Honeywell (2014), Smart cities } \\
\text { Building Automation }\end{array}$ \\
System & detector. & \\
& & \\
\hline
\end{tabular}




\begin{tabular}{|c|c|c|}
\hline IT Network Connectivity & $\begin{array}{l}\text { 1. Wired/wireless communication } \\
\text { 2. All devices connected with multi service } \\
\text { communication. } \\
\text { 3. Availability and reliability of network }\end{array}$ & $\begin{array}{l}\text { Buckman et al. (2014), Peeples (2016), } \\
\text { Supratman (2016) }\end{array}$ \\
\hline $\begin{array}{l}\text { Enterprise Management } \\
\text { System }\end{array}$ & $\begin{array}{l}\text { 1. Data management framework } \\
\text { 2. System information management. } \\
\text { 3. Data analytic }\end{array}$ & $\begin{array}{l}\text { Buckman et al. (2014), Frost and Sullivan } \\
\text { (2009), Honeywell (2014) }\end{array}$ \\
\hline $\begin{array}{l}\text { Green Building } \\
\text { Construction }\end{array}$ & $\begin{array}{l}\text { 1. Green building architecture } \\
\text { 2. Low environmental impact } \\
\text { 3. Resource efficiency } \\
\text { 4. Health environment }\end{array}$ & Buckman et al. (2014) \\
\hline $\begin{array}{l}\text { Safety and Security } \\
\text { Management System }\end{array}$ & $\begin{array}{l}\text { 1. Implementation of detection and response to } \\
\text { threat. } \\
\text { 2. Implementation of controlling access to the } \\
\text { facility. } \\
\text { 3. Implementation of securing framework and } \\
\text { cyber security. } \\
\text { 4. Publish safety and privacy policy. }\end{array}$ & Honeywell (2014), Supratman (2016) \\
\hline
\end{tabular}

Table 1 indicates numerous studies conducted on the indicators of smart buildings to achieve sustainability. Garau and Pavan (2018) asserted that there is not a general consensus on what the concept of smart building is, and at its core, the notion is premised on the networking of human capital, social capital and information and communication technologies (ICTs). This is seen to be supported by the level of infrastructure needed to promote sustainability challenges which include environmental, social and economic development, and can bring about a better quality of life (Caragliu et al., 2011; European Parliament, 2014; Vázquez et al., 2018). According to Fleischmann and Heuser (2015) and Chourabi et al. (2012), the transformation of an ordinary non-smart building to a smart building also entails networking its technological components with its political and institutional components.

According to World-GBC (2017), smart building approach may vary across regions and countries. However, research on SBTs and the indicators to achieve sustainability within the Ghanaian is deficient. For this research study, an empirical survey is performed to identify the significant indicators of accreditation of smart buildings that help to attain the goal of construction sustainability in Ghana, particularly in Greater Accra and Ashanti regions. According to the Central Intelligence Agency (2017), Accra and Kumasi represent the largest two cities of Ghana in terms of housing, infrastructure and population. Hence, achieving construction sustainability would have a significant impact upon national sustainable development (Darko, 2019). This can be achieved by incorporating SBTs into housing designs (Assari and Mahesh, 2011). Thus, it is important to help Architects and Project Managers to better understand how and what indicators can be ensured to attain smart building sustainability.

\section{Research Methodology}

An overarching post-positivist (cf. Al-Saeed et al., 2020; Mohamed et al., 2020) and empirical (cf. Edwards et al., 2020) epistemological design was adopted for this research to analyse primary quantitative data (Dixon et al., 2020). Post-positivism was achieved via the use of perception data collated via a structured questionnaire that was rigorously analysed using summary and inferential statistics - such being an established technique used 
throughout construction management literature (cf. Owusu-Manu et al., 2018). Because the research was grounded on the theory of ID, a deductive approach was employed to test this existing theory.

\section{Identification of Indicators of Smart Building}

Table 1 reports upon the number of indicators for measuring smartness of buildings. After a comprehensive review of relevant studies, 21 potential indicators for measuring smart building were identified. These factors were well documented in previous research and therefore, more applicable. According to Rowlinson (1988), it is more appropriate to use well-known factors for a research study therefore, helping respondents to respond easily.

\section{Data Collection}

The study adopted a quantitative research strategy where a structured questionnaire survey was adopted to help test the level of significance of the identified indicators in measuring smartness of a building. According to Tan (2011), a questionnaire survey is a systematic technique of data collection based on sample. The questionnaire was developed based on comprehensive literature review. Prior to the questionnaire survey, a pilot test was adopted to check the questionnaire's level of appropriateness and rationality. For pilot testing, the questionnaire was reviewed by selected academic and practitioner respondents to ensure that ambiguous expressions were not contained in the survey, and that appropriate technical terms were used. Based on the feedback, the questionnaire was finalized. In the questionnaire, the research objective and the contact details were first presented, followed by questions meant to gather background information of the respondents. Afterward, respondents were then requested to assess the identified indicators on measuring smart building based on the level of significance in measuring smartness of buildings using a five-point Likert scale (viz: ' 1 - not significant, 2 - less significant, 3 - moderate, 4 - significant and 5 - very significant'). Before the respondents were asked to rate the indicators, the study sought to know the level of knowledge of the respondents on indicators of smart buildings based on the Likert scale: ' 1 very low, 2 - low, 3 - moderate, 4 - high and 5 - very high'.

The targeted population comprised the Project Managers of construction firms, as well as the construction design team members including the Quantity Surveyor, Construction Manager, Architect, Electric Engineer, Structural Engineer, Mechanical Engineer, Planner, IT Specialist and Service Engineer. The study adopted Cochran's formula to calculate the sample size for the study due to the unknown population size (Cochran, 1963) within the 221 construction companies within Ghana viz:

$$
n_{0}=\frac{z^{2} \times p(1-p)}{e^{2}}
$$

$\mathbf{n}_{\mathbf{0}}=$ sample size, which needs to be estimated, $\mathbf{z}=$ selected critical value of desired level of confidence or risk; $95 \%$ confidence level (the value of $(1-\alpha)$ in standard normal distribution $\mathrm{z}$-table, which is 1.96 for $95 \%), \mathbf{p}=$ estimated proportion of an attribute that is present in the population or maximum variability of the population; $50 \%$ variability of the population (which is maximum), $\mathbf{e}=$ desired level of precision or margin of error; $5 \%$ margin of error.

$$
n_{0}=\frac{(1.96)^{2} \times 0.5(1-0.5)}{(0.05)^{2}}=384.16
$$


Consequently, the study employed a sample size of 385 construction professionals. Purposive sampling was adopted to collect data from targeted participants who are known to possess some qualities and experiences, as well as convenience sampling which is quick, inexpensive and convenient. The study retrieved 50 completed hardcopy questionnaires from the respondents, and 177 online filled questionnaires through 'Google Form'. The total number of questionnaires retrieved were 227, giving a response rate of $58.96 \%$. The study, therefore, approved the 58.96\% for further analysis because Goyder (1985) cited in Mellahi and Harris (2016) that the acceptable rate of survey responses ranges between $50 \%$ and $70 \%$.

\section{Data Analysis Technique}

\section{Cronbach's Alpha Technique}

According to Santos (1999), Cronbach's Alpha coefficient checks the reliability and consistency under the adopted scale of measurement, ranging from 0 to 1 , where 1 is the highest level of validity and reliability of quantitative inputs. Norušis (2011) asserted that the threshold for Cronbach's Alpha is 0.7, after which further analysis can be done. The Cronbach's Alpha for the scale for measuring the study's objective was 0.978 thus indicating that further analysis can commence using this scale.

\section{Means Score Ranking}

According to Cheung and Chan (2011), data acquired are analysed using a mean score ranking technique to determine the central agreement on variables. Mean score ranking has been broadly used in rating the relevance of the variables. Hence, the mean score was adopted to rank variables relating to the study's objectives to determine the central trend of the variables.

\section{Standard Deviation}

Standard deviation measures the spread of the data about the mean value (RevisionMaths, 2019). It is useful in comparing sets of data which may have the same mean but different range and consistency. Stevens (2012) asserted that a standard deviation of less than 1.0 indicates consistency in agreement among the respondents of the reported level of response. If a data set has a low standard deviation, the values are not spread out too much. The study again adopted standard deviation to report on the consistency in agreement among the project managers and the construction design teams.

\section{One Sample T-Test}

The one sample T-test compares the mean of sample data to a known value to determine whether a population mean is significantly different from a hypothesized value (Stephanie, 2015). A one sample T-test is known to compare the mean score found in an observable sample to some predetermined or hypothetical value. Typically, the hypothetical value is the population mean or some other theoretical derived value. The study therefore, adopted one sample T-test to measure the statistical significance of the mean values in relation to the research study.

\section{Survey Results}


Prior to analysing the indicators, the study adopted frequency to determine the level of awareness of smart building indicators and the respondents' demographic data. According to Research Optimus (2020), frequency in statistics is an important area that deals with the number of occurrences.

\section{Background Analysis of Respondents}

To increase the credibility and validity of the results, the demographic profile of respondents was recorded including their academic qualification and professional experience. This objective enhanced understanding of the participants' profile and increased the degree of confidence in the data including reliability and precision.

Table 2: Background Analysis of Respondents

\begin{tabular}{|c|c|c|c|}
\hline \multicolumn{2}{|l|}{ Variables } & \multirow{2}{*}{$\begin{array}{c}\text { Frequency } \\
93\end{array}$} & \multirow{2}{*}{$\begin{array}{c}\text { Cumulative } \\
\text { Frequency }\end{array}$} \\
\hline Academic & Bachelor of Science (BSc) & & \\
\hline Qualification & Masters of Science/Philosophy (MSc/MPhil) & 83 & 176 \\
\hline & Higher National Diploma (HND) & 33 & 209 \\
\hline & Doctor of Philosophy (PhD) & 17 & 226 \\
\hline & Other & 1 & 227 \\
\hline & Total & 227 & \\
\hline \multirow{6}{*}{$\begin{array}{ll}\text { Years } & \text { of } \\
\text { Experience }\end{array}$} & Less than 5 years & 84 & 84 \\
\hline & $5-10$ years & 92 & 176 \\
\hline & $11-15$ years & 39 & 215 \\
\hline & 16-20years & 10 & 225 \\
\hline & More 20 years & 2 & 227 \\
\hline & Total & 227 & \\
\hline
\end{tabular}

According to Hegarty et al. (2011), academic qualification is indicative of an individual's knowledge acquired for professional development and ability to build critical thinking. Therefore, an academic qualification plays a vital role of an organization resulting in success and satisfaction (Essay Sauce, 2015). The study involved the academic qualification in order to understanding the respondents' thinking capability. The study involved academic qualification consisting of, for example: Higher National Diploma (HND), Bachelor of Science (BSc), Masters of Science/Philosophy (MPhil) and Doctor of Philosophy (PhD). Table 2 depicts the result in relation to the academic qualification based on the responses from the research participants viz: PhD frequency $(f)=17$, MPhil $f=83$, BSc $f=93$ and HND $f=33$. Only 1 respondent chose other qualifications, which could mean the participant works with some form of certificate earned in industry or academia. This range of qualifications held illustrates that the respondents are academically inclined thus, increasing the credibility of the information accrued and consequential results derived.

Ascertaining the respondents' working experience is very important, as it also contributes to the credibility of information by giving relevance to the kind and quality of information 
given. According to DeRue (2009), work experience has been perceived to guarantee for both quality and quantity in performing a specific task. Usually, a respondent's years of experience in an organization is necessary, as they acquire more knowledge on work. Moreover, working experience can give an idea about the knowledge and adoption capabilities of SBTs in organizations. Drawing a conclusion from Table 2, 92 respondents were declared as having work experience of 5-10 years, followed by 'less than 5 years' $f=84$ respondents; ' $11-15$ years' $f=39$; ' $16-20$ years' $f=10$; and ' $\geq 20$ years' $f=2$. The result depicts that the respondents have accrued reasonable experience and a plausible conclusion is that the respondents are experienced in the construction industry and can make a decision towards the adoption of SBTs. Also, the idea of smart building is current and therefore, its adoption can relate to respondents with work experience below 15 years.

\section{Level of Knowledge on the Underlying Indicators of Accreditation of Smart Building}

Finn et al. (2000) described descriptive analysis as relevant facets representing a set of measurements and accounts for a mass of quantitative information. This offers an important foundation for examining the academic spheres on the underlying indicators to measure smart building in Ghana. Before respondents were asked to rate the indicators, the study sought to establish the respondents' level of knowledge of indicators of smart buildings based on the Likert scale: ' 1 - very low, 2 - low, 3 - moderate, 4 - high and 5 - very high'. Figure 2 shows the level of knowledge of the respondents on the indicators of smart building in frequencies. This graphical representation depicts that 104 respondents have a moderate level of knowledge on indicators of smart building, 73 respondents had high, 47 respondents had low, 2 respondents had very high and 1 respondent had low level of knowledge. The study can then deduce that the level of knowledge of participants on the indicators of smart building is convincing. This result is consistent with Das (2012), when asserted that, the focus of buildings has slowly shifted from just sustainable building to smart intelligent building. Therefore, the construction industry is capable of shifting towards the smart building concept, as well as achieving sustainability.

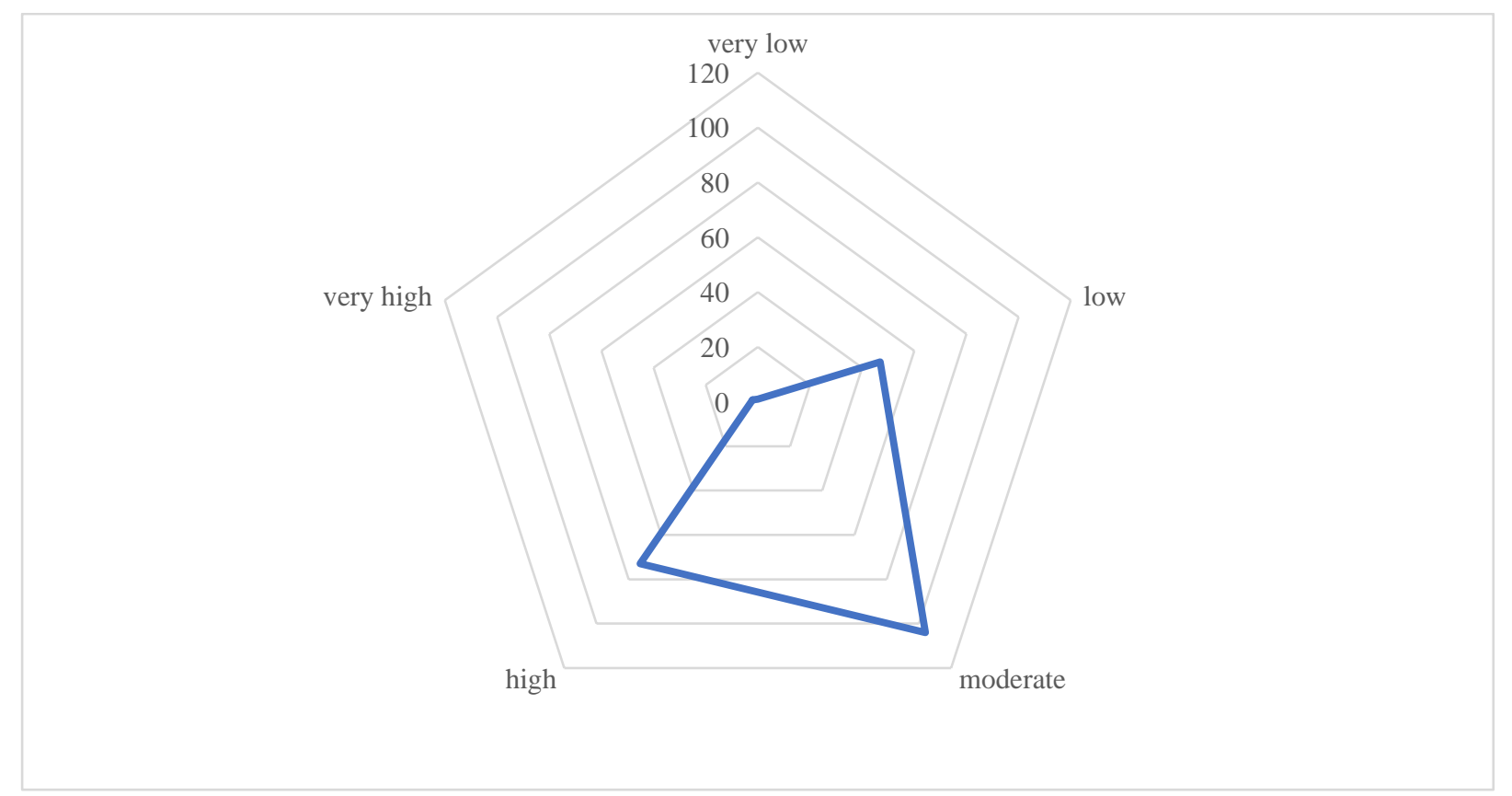




\section{Figure 2: Radar Diagram Indicating the frequency of the Level of Knowledge on Indicators of smart building}

\section{Result of Ranking Analysis}

From Table 3, the mean values or scores is $\geq 4$ ( 4 - significant), which means the responses from the participants clearly shows that all the indicators discovered from the literature review significantly measure smart building according to participants. The mean score indicated that 'sensors implementation to manage light level, air quality, temperature, fire alarm and smoke detector' was prioritized as the most used indicator to measure smart building - even though all other indicators can measure smart building (that is, their mean score were $\geq 4$ ).

In order of descending, the top 10 ranked indicators that are believed to measure smart building or capable of measuring smart building in Ghana are: 'sensors implementation to manage light level, air quality, temperature, fire alarm and smoke detector' (4.31), 'implementation of backup energy' (4.30), 'implementation of energy efficient electrical appliance' (4.30), 'implementation of detection and response to threat' (4.27), 'green building architecture' (4.25), 'wired/wireless communication' (4.25), 'healthy environment' (4.25), 'implementation of controlling access to the facility' (4.23), 'implementation of securing framework and cyber security' (4.23) and 'availability and reliability of network' (4.22). In overall, 'building automation system' was rated to be 1st (4.31) dimension in measuring smartness of buildings whilst 'building control system rated' rated the least 7 th (4.06). According to Buckman et al. (2014), building automation is an important component of smart building which includes the use of sensors to detect and response to humans. This present study's result concurs with Buckman et al. (2014) after revealing the building automation as the most significant indicator for measuring smart buildings. The results indicated that all the indicator dimensions are significant in measuring smart building, however a strong conclusion cannot be made based on descriptive analysis alone. Therefore, inferential analysis in the guise of a one sample T-test is adopted.

Again, the study reported the mean value of all the indicators to be $\leq 1.0$, therefore representing small amount of variation. Steven (2012) asserted that a standard deviation of $\leq$ 1.0 indicates consistency in agreement among respondents. The study therefore, indicates that the respondents' professional background and positions do not vary much with respect to the understanding of smart building indicators. Lastly, the univariate skewness and kurtosis was adopted to check the normality of data. According to Tabachnick and Fidell (2001), data is parametric if the values of skewness and kurtosis are equal to zero. Kline (2011) asserted that skewness is positive (high peak) when most of the values are below the mean and negative shows just the opposite. According to Everett (2013), using cut-off point $\leq 7$ as an acceptable value for the kurtosis and skewness to be within -2 to +2 range shows data are normally distributed. Table 3 reveals that the absolute value of univariate skewness to range from -1.6 to 1 , and that of univariate kurtosis to be $\leq 7$, thereby, depicting that the data does not unduly deviate from the normal distribution. Hence, the sample data could be used for further analysis. 
Table 3: Descriptive Analysis of Smart Building Indicators

\begin{tabular}{|c|c|c|c|c|c|c|c|}
\hline Code & Indicators & Mean & $\begin{array}{c}\text { Std. } \\
\text { Deviation }\end{array}$ & Skewness & Kurtosis & $\begin{array}{l}\text { Within } \\
\text { Ranking }\end{array}$ & $\begin{array}{c}\text { Overall } \\
\text { Ranking }\end{array}$ \\
\hline & Building Control system & 4.06 & 0.916 & & & & 7 \\
\hline IN01 & $\begin{array}{l}\text { Remote implementation monitors } \\
\text { building conditions and occupancy }\end{array}$ & 4.07 & 0.924 & -0.922 & 0.442 & 2 & 20 \\
\hline IN02 & Real time monitoring & 4.11 & 0.860 & -1.066 & 1.239 & 1 & 18 \\
\hline \multirow[t]{2}{*}{ IN03 } & $\begin{array}{l}\text { Implementation of any software that } \\
\text { can talk to legacy equipment from } \\
\text { many different manufactures }\end{array}$ & 4.01 & 0.964 & -0.915 & 0.499 & 2 & 21 \\
\hline & Energy Management System & 4.26 & 0.852 & & & & 2 \\
\hline IN04 & $\begin{array}{l}\text { Implementation of power consumption } \\
\text { monitoring and control }\end{array}$ & 4.19 & 0.875 & -1.260 & 1.982 & 3 & 12 \\
\hline IN05 & $\begin{array}{l}\text { Implementation of energy efficient } \\
\text { electrical appliance. }\end{array}$ & 4.30 & 0.861 & -1.501 & 2.553 & 2 & 3 \\
\hline \multirow[t]{2}{*}{ IN06 } & Implementation of backup energy & 4.30 & 0.820 & -1.343 & 2.147 & 1 & 2 \\
\hline & Building Automation System & 4.31 & 0.816 & & & & 1 \\
\hline \multirow[t]{2}{*}{ IN07 } & $\begin{array}{l}\text { Sensors implementation to manage } \\
\text { light level, air quality, temperature, fire } \\
\text { alarm and smoke detector. }\end{array}$ & 4.31 & 0.816 & -4.413 & 2.459 & 1 & 1 \\
\hline & IT Network Connectivity & 4.22 & 0.851 & & & & 4 \\
\hline IN08 & Wired/wireless communication & 4.25 & 0.821 & -1.309 & 2.426 & 11 & 5 \\
\hline IN09 & $\begin{array}{l}\text { All devices connected with multi } \\
\text { service communication. }\end{array}$ & 4.18 & 0.845 & -1.120 & 1.355 & 3 & 15 \\
\hline \multirow[t]{2}{*}{ IN10 } & Availability and reliability of network & 4.22 & 0.886 & -1.380 & 2.203 & 2 & 10 \\
\hline & Enterprise Management System & 4.15 & 0.886 & & & & 6 \\
\hline IN11 & Data management framework & 4.16 & 0.868 & -1.051 & 1.056 & 2 & 17 \\
\hline IN12 & System information management & 4.19 & 0.906 & -1.402 & 2.282 & 1 & 14 \\
\hline \multirow[t]{2}{*}{ IN13 } & Data analytic & 4.10 & 0.884 & -1.130 & 1.414 & 3 & 19 \\
\hline & Green Building Construction & 4.22 & 0.872 & & & & 5 \\
\hline IN14 & Green building architecture & 4.25 & 0.879 & -1.262 & 1.455 & 2 & 6 \\
\hline IN15 & Low environmental impact & 4.19 & 0.899 & -1.266 & 1.761 & 4 & 13 \\
\hline IN16 & Resource efficiency & 4.19 & 0.861 & -1.141 & 1.332 & 3 & 11 \\
\hline \multirow[t]{2}{*}{ IN17 } & Healthy environment & 4.25 & 0.847 & -1.244 & 1.681 & 1 & 7 \\
\hline & $\begin{array}{l}\text { Safety and Security Management } \\
\text { System }\end{array}$ & 4.23 & 0.853 & & & & 3 \\
\hline IN18 & $\begin{array}{l}\text { Implementation of detection and } \\
\text { response to threat }\end{array}$ & 4.27 & 0.838 & -1.316 & 1.972 & 1 & 4 \\
\hline IN19 & $\begin{array}{l}\text { Implementation of controlling access to } \\
\text { the facility }\end{array}$ & 4.23 & 0.827 & -1.216 & 1.811 & 2 & 8 \\
\hline IN20 & $\begin{array}{l}\text { Implementation of securing framework } \\
\text { and cyber security }\end{array}$ & 4.23 & 0.857 & -1.225 & 1.566 & 3 & 9 \\
\hline IN21 & Publish safety and privacy policy & 4.18 & 0.891 & -1.384 & 2.214 & 4 & 16 \\
\hline
\end{tabular}

\section{Statistical Significance of The Indicators on Measuring Smart Building (Using One Sample T-Test)}

A one sample t-test was again employed to check if the identified indicators are significant in measuring smart building based on the responses from participants, and also to draw a strong conclusion based on the result. The respondents were requested to check how the indicators measure smart building based on significant level using the 5-point Likert scale: ' 1 - not significant, 2 - less significant, 3 - moderate, 4 - significant and 5 - very significant'. 
At $95 \%$ confidence level with $p$-value of $\leq 0.05$, and a test value of 4 (4-significant), one sample T-test was adopted to determine statistical significance of the indicators of smart building. The study adopted 4 as the test value for one sample T-test with the reason that 4 signifies the significance level of all the indicators, and therefore, the indicators need to measure the smart buildings significantly. The null hypothesis, H0, is that "the mean value is statistically insignificant" whilst the alternative hypothesis, H1, is that "the mean value is statistically significant." This then implies that; the null hypothesis would be rejected once its $\mathrm{P}$-value is $\leq 0.05$. in using one sample $\mathrm{T}$-test, it is expected that the format includes $\mathrm{t}$ statistics, the degree of freedom (df), the p-value, the mean difference and the upper and lower limits of confidence level (Ahadzie, 2007).

From Table 4, the study had all the standard errors being closer to zero (0), which indicates that there is a minimal variability between means of different samples therefore, samples are likely to be accurate representation of the population (Field, 2005). The study also had all the t-values (strength of the test) for the indicators to be positive which depicts that their means are above the hypothesized 4.0. Most of the variables had their p-value being (significance of the test) $\leq 0.05$ which reveals that they are statistically significant (null hypothesis rejected), except 'remote implementation monitors building conditions and occupancy', 'implementation of any software that can talk to legacy equipment from many different manufactures' and 'data analytic which had the p-value > 0.05 (null hypothesis not rejected).

Table 4: One Sample T-test

\begin{tabular}{|c|c|c|c|c|c|c|c|c|}
\hline \multicolumn{9}{|c|}{ One Sample T-test } \\
\hline \multirow[t]{3}{*}{ Code } & \multirow[t]{3}{*}{ Indicators } & \multicolumn{7}{|c|}{ Test Value $=4.0$} \\
\hline & & \multirow[t]{2}{*}{$\mathbf{t}$} & \multirow[t]{2}{*}{ Df } & \multirow[t]{2}{*}{$\begin{array}{l}\text { Sig. (2- } \\
\text { tailed) }\end{array}$} & \multirow[t]{2}{*}{$\begin{array}{c}\text { Mean } \\
\text { Difference }\end{array}$} & \multicolumn{2}{|c|}{$\begin{array}{l}95 \% \text { Confidence } \\
\text { Interval of the } \\
\text { Differences }\end{array}$} & \multirow[t]{2}{*}{$\begin{array}{c}\text { Null } \\
\text { Hypothesis }\end{array}$} \\
\hline & & & & & & Lower & Upper & \\
\hline & \multicolumn{8}{|l|}{ Building Control system } \\
\hline IN01 & $\begin{array}{l}\text { Remote implementation } \\
\text { monitors building conditions } \\
\text { and occupancy }\end{array}$ & 1.150 & 226 & 0.252 & 0.070 & -0.05 & 0.19 & Not rejected \\
\hline IN02 & Real time monitoring & 2.007 & 226 & 0.046 & 0.115 & 0.00 & 0.23 & Rejected \\
\hline \multirow[t]{2}{*}{ IN03 } & $\begin{array}{l}\text { Implementation of any software } \\
\text { that can talk to legacy } \\
\text { equipment from many different } \\
\text { manufactures }\end{array}$ & 0.138 & 226 & 0.891 & 0.009 & -0.12 & 0.13 & Not rejected \\
\hline & \multicolumn{8}{|l|}{ Energy Management System } \\
\hline IN04 & $\begin{array}{l}\text { Implementation of power } \\
\text { consumption monitoring and } \\
\text { control }\end{array}$ & 3.263 & 226 & 0.001 & 0.189 & 0.08 & 0.30 & Rejected \\
\hline IN05 & $\begin{array}{l}\text { Implementation of energy } \\
\text { efficient electrical appliance. }\end{array}$ & 5.241 & 226 & 0.000 & 0.300 & 0.19 & 0.41 & Rejected \\
\hline \multirow[t]{2}{*}{ IN06 } & $\begin{array}{l}\text { Implementation of backup } \\
\text { energy }\end{array}$ & 5.584 & 226 & 0.000 & 0.304 & 0.20 & 0.41 & Rejected \\
\hline & \multicolumn{8}{|l|}{ Building Automation System } \\
\hline \multirow[t]{2}{*}{ IN07 } & $\begin{array}{l}\text { Sensors implementation to } \\
\text { manage light level, air quality, } \\
\text { temperature, fire alarm and } \\
\text { smoke detector. }\end{array}$ & 5.695 & 226 & 0.000 & 0.308 & 0.20 & 0.42 & Rejected \\
\hline & IT Network Connectivity & & & & & & & \\
\hline IN08 & Wired/wireless communication & 4.529 & 226 & 0.000 & 0.247 & 0.14 & 0.35 & Rejected \\
\hline
\end{tabular}




\begin{tabular}{|c|c|c|c|c|c|c|c|c|}
\hline IN09 & $\begin{array}{l}\text { All devices connected with } \\
\text { multi service communication. }\end{array}$ & 3.108 & 226 & 0.002 & 0.176 & 0.06 & 0.29 & Rejected \\
\hline \multirow[t]{2}{*}{ IN10 } & $\begin{array}{l}\text { Availability and reliability of } \\
\text { network }\end{array}$ & 3.819 & 226 & 0.000 & 0.225 & 0.11 & 0.34 & Rejected \\
\hline & $\begin{array}{l}\text { Enterprise Management } \\
\text { System }\end{array}$ & & & & & & & \\
\hline IN11 & Data management framework & 2.753 & 226 & 0.006 & 0.159 & 0.05 & 0.27 & Rejected \\
\hline IN12 & $\begin{array}{ll}\text { System } & \text { information } \\
\text { management } & \end{array}$ & 3.224 & 226 & 0.001 & 0.194 & 0.08 & 0.31 & Rejected \\
\hline \multirow[t]{2}{*}{ IN13 } & Data analytic & 1.727 & 226 & 0.086 & 0.101 & -0.01 & 0.22 & Not rejected \\
\hline & Green Building Construction & & & & & & & \\
\hline IN14 & Green building architecture & 4.303 & 226 & 0.000 & 0.251 & 0.14 & 0.37 & Rejected \\
\hline IN15 & Low environmental impact & 3.173 & 226 & 0.002 & 0.189 & 0.07 & 0.31 & Rejected \\
\hline IN16 & Resource efficiency & 3.393 & 226 & 0.001 & 0.194 & 0.08 & 0.31 & Rejected \\
\hline \multirow[t]{2}{*}{ IN17 } & Healthy environment & 4.388 & 226 & 0.000 & 0.247 & 0.14 & 0.36 & Rejected \\
\hline & $\begin{array}{l}\text { Safety and Security } \\
\text { Management System }\end{array}$ & & & & & & & \\
\hline IN18 & $\begin{array}{l}\text { Implementation of detection } \\
\text { and response to threat }\end{array}$ & 4.833 & 226 & 0.000 & 0.269 & 0.16 & 0.38 & Rejected \\
\hline IN19 & $\begin{array}{l}\text { Implementation of controlling } \\
\text { access to the facility }\end{array}$ & 4.253 & 226 & 0.000 & 0.233 & 0.13 & 0.34 & Rejected \\
\hline IN20 & $\begin{array}{l}\text { Implementation of securing } \\
\text { framework and cyber security }\end{array}$ & 4.026 & 226 & 0.000 & 0.229 & 0.12 & 0.34 & Rejected \\
\hline IN21 & $\begin{array}{l}\text { Publish safety and privacy } \\
\text { policy }\end{array}$ & 3.053 & 226 & 0.003 & 0.181 & 0.06 & 0.30 & Rejected \\
\hline
\end{tabular}




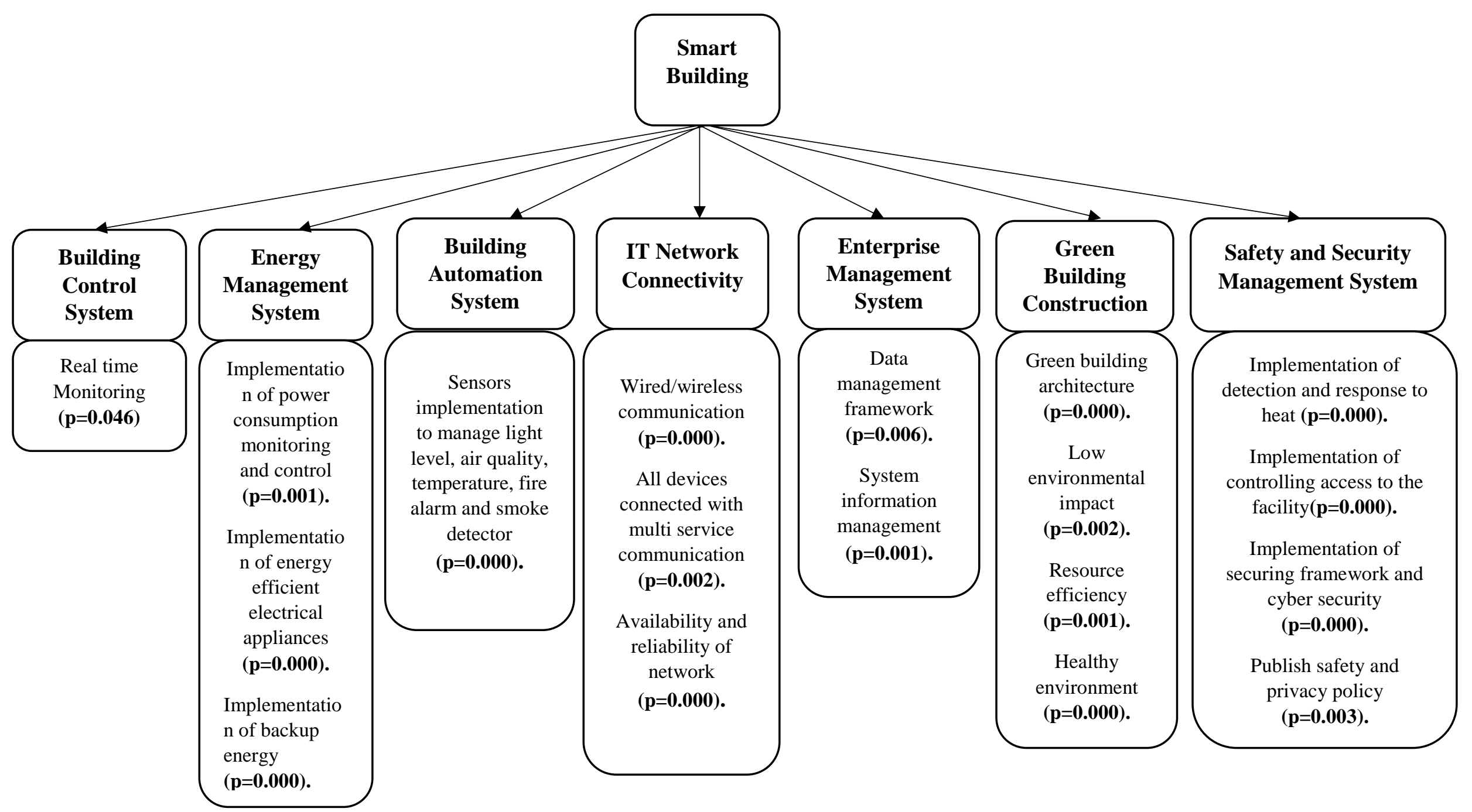

Figure 3: Proposed Framework to Measure Smartness of Buildings in Ghana (Based on the significant level (P-value) of the Indicators) 


\section{Discussion of Results}

The study achieved its objective and indicated that 'sensors implementation to manage light level, air quality, temperature, fire alarm and smoke detector' was prioritized as the most significant indicator to measure smart building, even though all other indicators stand to measure smart building. This result concurs with the research findings by Buckman et al. (2014) who reveal that sensor network use is key to achieving high performance buildings, and Indrawati et al. (2017) who proffer that sensors are a key indicator for smart building.

The study also discovered that, the top ten ranked indicators in measuring the concept of smart building are: 'sensors implementation to manage light level, air quality, temperature, fire alarm and smoke detector', 'implementation of backup energy', 'implementation of energy efficient electrical appliance', 'implementation of detection and response to threat', 'green building architecture', 'wired/wireless communication', 'healthy environment', 'implementation of controlling access to the facility', 'implementation of securing framework and cyber security' and 'availability and reliability of network'. This is consistent with BaltaOzkan et al. (2014) when posited that smart buildings are equipped with communication networks, linking sensors and devices that can be remotely be controlled, accessed and monitored by providing responses to the needs of the inhabitants. Bosch-Sijtsema et al. (2017) also revealed the key performance indicators of improving the performance of a building by considering health and cyber security (cf. Pärn and Edwards, 2019), which is consistent to the finding of the current study on including the system of 'implementation of securing framework and cyber security' and 'healthy environment' as part of the key indicators for the accreditation of smart building. Hoy (2016) asserted that smart building is an umbrella term for describing a number of different technologies that are integrated into buildings, and this study reveals the indicators that are described as technologies needed to be integrated into buildings. Berst (2013) suggests that to adopt complex innovations like SBTs, the government must prioritize digital technologies/instrumentations that can capture all relevant data and information. The study has revealed the significant characteristics that the construction industry in Ghana and other developing country could similarly learn from this analysis and ensuing discourse.

The study also validates the theory of ID in relation to the concept of smart building by laying out the intelligent systems (indicators) capable of achieving the nature and complexity of smart building (Gilder and Clement-Croome, 2010). Being able to integrate these systems into conventional buildings is capable of lowering cost and energy usage due to the ability of improving building performance (Hume, 2013, Indrawati et al., 2017). From Assari and Mahesh (2011) and Darko (2019), high building performance can be achieved by incorporating indicators of smart building into housing designs. Based on the result, a model consisting of the significant indicators for measuring smartness of a building has been developed to help improve the performance of buildings (Figure 3). The study discovered the indicators for measuring smart building from a comprehensive literature review but based on testing the statistical significance, different indicators were identified. The study revealed statistically that, priority is not put on 'remote implementation monitors building conditions and occupancy', 'implementation of any software that can talk to legacy equipment from many different manufactures' and 'data analytic' when measuring smartness of a building. Practically, this study can be utilised by policy makers and practitioners as 'blueprint guidance' to appreciate and adopt the idea of significant smart building indicators to improve building performance. The study has revealed the significant indicators that measure the smartness of buildings or smart buildings to policy makers and construction practitioners in their decision making towards achieving sustainability. To academia, the study will help 
comprehend a more lucid understanding of the smart buildings concept and its key features such knowledge will provide much needed polemic debate and future avenues for further research investigation. Future work is required to transform the blueprint guidance into a practical tool that can be readily utilised by practitioners who may not have statistical knowledge and knowhow. At this juncture, it is envisaged that a simple software tool could be developed using MS Excel or similar widely available software which would ensure the widest possible adoption rate.

\section{Conclusions}

To investigate the underlying indicators in measuring smart building in the construction industry, 21 indicators were identified from a comprehensive review of relevant literature. Through a structured questionnaire survey with 227 responses from project managers and construction design teams of construction companies in Ghana, the indicators for measuring smart building were established. In attaining the objective, the study sought to check the level of knowledge of the respondent on the indicators of smart building based on the Likert scale: ' 1 - very low, 2 - low, 3 - moderate, 4 - high and 5 - very high'. Using frequency, the result deduced from the data analysis revealed that the general level of knowledge of smart building indicators of participants is moderate and convincing and therefore, still needs to be encouraged. The respondents were then requested to rank how significantly the 21 identified indicators measure smart building based on the 5-point Likert scale: ' $1=$ not significant, 2 less significant, 3 - moderate, 4 - significant and 5 - very significant'. The use of mean score indicated that 'sensors implementation to manage light level, air quality, temperature, fire alarm and smoke detector' was prioritized as the most indicator to measure smart building, even though all other indicators stand to measure smart building (that is, their mean score were $>4$. Also, the use of one sample T-test for the study revealed that 'remote implementation monitors building conditions and occupancy', 'implementation of any software that can talk to legacy equipment from many different manufactures' and 'data analytic' is not statistically significant in measuring the smartness of building. Therefore, in conclusion, when measuring smart building indicators, priority is not put on 'remote implementation monitors building conditions and occupancy', 'implementation of any software that can talk to legacy equipment from many different manufactures' and 'data analytic'. The study's findings revealed that the level of knowledge of smart building indicators is averagely high in the Ghanaian construction industry. With regards to all the indicators of smart building, 'sensors implementation to manage light level, air quality, temperature, fire alarm and smoke detector' is regarded as the most significant measure of smart buildings. Also, 'remote implementation monitors building conditions and occupancy', 'implementation of any software that can talk to legacy equipment from many different manufactures' and 'data analytic' are statistically insignificant in measuring smart buildings in Ghana. Based on the result, a model consisting of significant indicators for measuring smartness of a building has been developed to help improve the performance of buildings in the construction industry using one sample T-test.

The practical implication is that, to improve the performance of buildings, construction professionals and policy makers need to take a proactive role in knowing the indicators of smart buildings. For instance, if the significant underlying indicators for smartness of buildings are made known to all actors in the construction industry supply chain, the unawareness of smart technologies can be addressed, and stakeholders will be encouraged to adopt SBTs. Also, the policy makers should promote and encourage SBTs research and development within both the public and the private sector. As per results presented, it may be 
crucial for the construction industry to fully support and promote SBTs adoption because they may help in improving the performances of buildings towards sustainability. Practically, the identified significant indicators can be applied as a 'blueprint guidance' to measure smart buildings in developing countries based on their level of significance as revealed by this study. Therefore, the study provides developers and building stakeholders with a consolidated inclusive tool for achieving efficient building performance in the construction industry. Albeit, further work is required to generate a user friendly graphic user interface to apply the tool's scientific underpinning.

The study's findings could be of great value and utility for researchers, policy makers, industry practitioners and advocates seeking empirical quantitative evidence and explanations vis-à-vis the significant indicators for improving the smartness and performances of building. A clear understanding of the indicators of smartness of a building could significantly influence the adoption of SBTs in the construction industry. The awareness of the significant underlying indicators for measuring smartness of a building is significantly related to SBTs adoption and therefore, can help policy makers and advocates to devise appropriate strategies to mitigate the associated barriers; hence promoting SBTs adoption. Regards the existing body of knowledge, the key contribution this study makes is by identifying the significant indicators measuring the smartness of buildings which further influence SBTs adoption in the construction industry. The study makes clear the significant attributes that needs to be incorporated into buildings to help achieve the smart building concept in the construction industry, thereby improving buildings' performance. Also, the identified significant indicators make the added value of building smartness more tangible for building users, owners, tenants and service providers. Specifically, the identified indicators provide information on the technological readiness of buildings to interact with their occupants and the energy grid. Similarly, the study demonstrates the building's capabilities for more efficient operation and better performance through technologies.

Although the objective was achieved in establishing the significant indicators for measuring smart building, the study still has some limitations that are worth mentioning. These limitations not only warrant future studies but must be considered in the result interpretation and generalization. First, the findings are geographically limited to Ghana vis-à-vis other developing countries. Nevertheless, this does not limit the generalizability of the study, since it can be used as a lesson to other developing countries. Also, the analysis and conclusion of this study were based on data collated from participants by means of the data collection tool (questionnaire) via only quantitative research strategy. Only 21 indicators were carefully reviewed, refined and selected to measure the smartness of a building therefore, liable of imposing limitation to the study but does not limit the generalizability of the result. The findings and implications of this study may be useful to policy makers, practitioners, stakeholders and advocates in other, especially developing countries around the world. The results may also be useful to foreign and international organizations interested in understanding and adopting SBTs within Ghana. Based on the findings, practitioners, policy makers and advocates may devise an effective implementation strategy that could help promote SBTs adoption in the construction industry in other, especially developing countries around the world. It is necessary to consider the future studies regarding the adoption of SBTs because adoption activities become more matured. While this study reports on the indicators for measuring smart building, the future should evaluate the awareness level of SBTs by construction professionals. The study recommends that, future study could also analyse the difference and similarities between the SBTs adoption barriers in Ghana and many more developed/developing countries. 


\section{Reference}

Addy, M. N, Adinyira, E. and Koranteng, C., (2014). Architect's perception on the challenges of building energy efficiency in Ghana. Structural Survey, 32(5), pp. 365-376, https://doi.org/10.1108/SS-03-2014-0014.

Addy, N. M., Adinyira, E. and Joshua, A., (2017). Developing a Building Energy Efficiency Assessment Tool for Office Buildings in Ghana: Delphic Consultation Approach. Energy Procedia, 111, pp.629-638, https://doi.org/10.1016/j.egypro.2017.03.225.

Agarwal, Y., Balaji, B., Gupta, R., Lyles, J., Wei, M. and Weng, T., (2010), November. Occupancydriven energy management for smart building automation. In Proceedings of the 2nd ACM workshop on embedded sensing systems for energy-efficiency in building (pp. 1-6). ACM, https://doi.org/10.1145/1878431.1878433.

Ahadzie, D. K., (2007), "A Model for Predicating the Performance of Project Managers in Mass House Building Projects in Ghana", Published PhD Thesis, University of Wolverhampton, $\mathrm{UK}$,

https://wlv.openrepository.com/bitstream/handle/2436/15393/Ahadzie PhD\%20?sequence=2, Accessed: 05/6/2020.

Ahiabor, G., (2019), Smart buildings are coming: But who holds the keys? https://www.graphic.com.gh/news/general-news/smart-buildings-are-coming-but-who-holdsthe-keys.html, Accessed: 17/08/2019.

Al-Saeed, Y., Edwards, D. and Scaysbrook, S. (2020) Automating construction manufacturing procedures using BIM digital objects (BDOs): Case study of knowledge transfer partnership project in UK, Construction Innovation, Vol. ahead-of-print No. ahead-of-print. DOI: https://doi.org/10.1108/CI-12-2019-0141.

Apanaviciene, R., Vanagas, A. and Fokaides, P.A., 2020. Smart Building Integration into a Smart City (SBISC): Development of a New Evaluation Framework. Energies, 13(9), p.2190, https://doi.org/10.3390/en13092190, Accessed: 05/06/2020.

Arkin, H. and Paciuk, M., (1997). Evaluating intelligent buildings according to level of service systems integration. Automation in Construction, 6(5-6), pp.471-479, https://doi.org/10.1016/S0926-5805(97)00025-3.

Assari, A., and Mahesh, T. M. (2011). Demographic comparative in heritage texture of Isfahan City, Journal of Geography and Regional Planning, 4(8), pp. 463-570, https://academicjournals.org/article/article1381844733_Assari\%20and\%20Mahesh.pdf, Accessed: 05/06/2020.

Attoue, N., Shahrour, I. and Younes, R., (2018). Smart building: Use of the artificial neural network approach for indoor temperature forecasting. Energies, 11(2), pp.395, https://doi.org/10.3390/en11020395.

Baleta, J., Mikulčić, H., Klemeš, J.J., Urbaniec, K., and Duić, N., (2019). Integration of energy, water and environmental systems for a sustainable development. Journal of Cleaner Production, 215, pp. 1424-1436, https://doi.org/10.1016/j.jclepro.2019.01.035.

Balta-Ozkan, N., Boteler, B., and Amerighi, O. (2014). European smart home market development: Public views on technical and economic aspects across the United Kingdom, German and Italy. Energy Research \& Social Science, 3, pp.65-77, https://doi.org/10.1016/j.erss.2014.07.007.

Berst, J. (2013). The planning manual for building tomorrow's cities today. Seattle: Smart City Council,

http://www.estudislocals.cat/wpcontent/uploads/2016/11/SmartCitiesReadinessGuide.pdf, Accessed: 05/06/2020.

Bosch-Sijtsema, P., Isaksson, A., Lennartsson, M. and Linderoth, H.C., (2017). Barriers and facilitators for BIM use among Swedish medium-sized contractors- "We wait until someone tells us to use it". Visualization in engineering, 5(1), pp.3, https://doi.org/10.1186/s40327$\underline{017-0040-7 .}$. 
Buckman, A.H., Mayfield, M. and BM Beck, S., (2014). What is a smart building? Smart and Sustainable Built Environment, 3(2), pp. 92-109, https://doi.org/10.1108/SASBE-01-20140003.

Caragliu, A., Del Bo, C. and Nijkamp, P., (2011). Smart cities in Europe. Journal of urban technology, 18(2), pp.65-82, https://doi.org/10.1080/10630732.2011.601117.

Central Intelligence Agency (2017), The World Factbook, https://www.cia.gov/library/publica\%20tio\%20ns/the-world-factbook/geos/gh.html,

(Accessed: 24 September, 2019).

Chan, A.P.C., Darko, A., Olanipekun, A.O. and Ameyaw, E.E., (2018). Critical barriers to green building technologies adoption in developing countries: The case of Ghana. Journal of cleaner production, 172, pp.1067-1079, https://doi.org/10.1016/j.jclepro.2017.10.235.

Cheung, D.W. and Chan, A.P., (2011). Risk ranking and analysis in target cost contracts: Empirical evidence from the construction industry. International Journal of Project Management, 29(6), pp.751-763, https://doi.org/10.1016/j.ijproman.2010.08.003.

Chourabi, H., Nam, T., Walker, S., Gil-Garcia, J.R., Mellouli, S., Nahon, K., Pardo, T.A. and Scholl, H.J., (2012), January. Understanding smart cities: An integrative framework. In 2012 45th Hawaii international conference on system sciences, pp. 2289-2297. IEEE, https://doi.org/10.1109/HICSS.2012.615.

Cochran, W. G. (1963). Sampling Techniques, 2nd Ed., New York: John Wiley and Sons, Inc, https://www.scirp.org/(S(i43dyn45teexjx455qlt3d2q))/reference/ReferencesPapers.aspx?Refe renceID=1837525, Accessed: 05/06/2020.

Darko, A., (2019). Adoption of Green Building Technologies in Ghana: Development of a Model of Green Building Technologies and Issues Influencing their Adoption, Doctor of Philosophy Thesis, The Hong Kong Polytechnic University, Hong Kong, http://www.bre.polyu.edu.hk/people/RS/HKPolyU_BRE_RS_AMOS\%20DARKO.pdf, Accessed: 05/06/2020.

Das, S., (2012). POE Framework for Assessing User Connectivity of Intelligent Buildings. Bonfring International Journal of Industrial Engineering and Management Science, 2(4), pp.51-56, https://doi.org/10.9756/BIJIEMS.1722.

DeRue, D.S., (2009). Quantity or quality? Work experience as a predictor of MBA student success. GMAC Research Reports RR-09, 9, http://www.gmac.com/NR/rdonlyres/FEDDBF2B-0BCF43FD-B8E6-82C9641A38CC/0/RR0909_WorkExperienceV1.pdf, Accessed: 05/06/2020.

Dixon, C., Edwards, D.J., Lai, H.K., Garcia-Mateo, M., Thwala, W.D., and Shelbourne, M. (2020) An investigation into the erroneous access and egress behaviours of building users and their impact upon building performance. Facilities. DOI: https://doi.org/10.1108/F-05-2019-0053

Edwards, D. J., Pärn, E. A., Love, P. E. D. and El-Gohary, H. (2017) Machinery, manumission and economic machinations. Journal of Business Research, 70, pp. 391-394. DOI: https://doi.org/10.1016/j.jbusres.2016.08.012

Edwards, D.J., Rillie, I., Chileshe, N. Lai, J., Hossieni , M. Reza, and Thwala, W.D. (2020) A field survey of hand-arm vibration exposure in the UK utilities sector, Engineering, Construction and Architectural Management. DOI: https://doi.org/10.1108/ECAM-09-2019-0518

Essay Sauce (2015), Essay: The importance of academic qualifications, https://www.essaysauce.com/education-essays/essay-the-importance-of-academicqualifications/, Accessed; 16/02/2020.

European Parliament (2014). Mapping Smart Cities in the EU, European Parliament, Directorate General for Internal Policies: Brussels, Belgium, https://op.europa.eu/en/publication-detail//publication/78882e80-fc4a-4a86-9c39-2ad88ab89f9b, Accessed: 05/06/2020.

European Union, (2014)., Energy Strategy and Energy Union, https://ec.europa.eu/energy/en/topics/energy-strategy-and-energy-union/2020-energy-strategy, Accessed: 17.08/2019.

Evans, M., Halverson, M., Delgado, A. and Yu, S., (2014). Building energy code compliance in developing countries: the potential role of outcomes-based codes in India. In the Proceedings of the ACEEE Summer Study on Energy Efficiency in Buildings (pp. 8-61), https://pdfs.semanticscholar.org/26ac/090cd51b296ac039016c4691578d84832881.pdf,

Accessed: 05/06/2020. 
Everett, B., (2013). An introduction to latent variable models. Springer Science \& Business Media, https://www.springer.com/gp/book/9789401089548, Accessed: 05/06/2020.

Field, A., (2005), "Discovering Statistics using SPSS for Windows", London: Sage Publication, https://pdfs.semanticscholar.org/463d/c5de03c98e360b97d01dcac7a71a9a439dcc.pdf,

Accessed: 05/06/2020.

Finn, M., Walton, M. and Elliott-White, M., (2000). Tourism and leisure research methods: Data collection, analysis, and interpretation. Pearson education, https://pdfs.semanticscholar.org/3be3/a23e2f68f688a04b8ff450b675f02b940310.pdf, Accessed: 05/06/2020.

Fleischmann, A. and Heuser, L. (2015). Society Requirements and Acceptance of the Smart City Programs. Available online: http://smartpolis.eit.bme.hu/sites/default/files/D3.1_Soc.\%20req.\%20and\%20acceptance\%20 of\%20the\%20smart\%20city\%20programs.pdf, (Accessed on 25/09/2019).

Frost and Sullivan, (2009), Strategic Opportunity Analysis of the Global Smart City Market, Maxim, Perevesentsev: Kazakhstan, Tidak diterbitkan, https://dsimg.ubmus.net/envelope/153353/295862/1391029790_strategic_opportunity.pdf, $\quad$ Accessed: 05/06/2020.

Garau, C. and Pavan, V., (2018). Evaluating urban quality: indicators and assessment tools for smart sustainable cities. Sustainability, 10(3), pp.575, https://doi.org/10.3390/su10030575.

Gilder, J. and Clements-Croome, D.J., (2010), May. Bio inspired intelligent design for the future of buildings. In Building a Better World: CIB World Congress, https://www.researchgate.net/profile/D Clements-Croome/publication/258233090 Bio inspired Intelligent design for the future of Buildings/links/55f2cdee08ae51c380c005cc. pdf, Accessed: 05/06/2020.

Gungor, V.C., Sahin, D., Kocak, T., Ergut, S., Buccella, C., Cecati, C. and Hancke, G.P., (2011). Smart grid technologies: Communication technologies and standards. IEEE transactions on Industrial informatics, 7(4), pp.529-539, https://doi.org/10.1109/TII.2011.2166794.

Gyamfi, S., Diawuo, F.A., Kumi, E.N., Sika, F. and Modjinou, M., (2018). The energy efficiency situation in Ghana. Renewable and Sustainable Energy Reviews, 82, pp.1415-1423, https://doi.org/10.1016/j.rser.2017.05.007.

Harkouss, F., Fardoun, F., and Biwole, P.H., (2018). Optimization approaches and climates investigations in NZEB: A review. Building Simulation, 11(5), pp. 923-952, https://doi.org/10.1007/s12273-018-0448-6.

Hegarty, P.M., Kelly, H.A. and Walsh, A., (2011). Reflection in a workplace qualification: challenges and benefits. Journal of Workplace Learning, 23(8), pp.1366-5626. https://doi.org/10.1108/13665621111174889.

Honeywell (2014), Put Your Buildings To Work: A Smart Approach To Better,https://www.forbes.com/sites/honeywell/2016/10/28/why-we-need-smart buildings/\#43089b5777d9, Accessed: 10/09/2019.

Hoy, M.B., (2016). Smart buildings: an introduction to the library of the future. Medical reference services quarterly, 35(3), pp.326-331, http://dx.doi.org/10.1080/02763869.2016.1189787.

Hui, S.C., (2000). Building energy efficiency standards in Hong Kong and mainland China. In Proc. of the 2000 ACEEE Summer Study on Energy Efficiency in Buildings, pp. 20-25, https://www.eceee.org/static/media/uploads/site-

2/library/conference_proceedings/ACEEE_buildings/2000/Panel_9/p9_17/paper.pdf, Accessed: 05/06/2020.

Hume, D., (2013). Irisys technology adds intelligence to smart buildings. Exploring what is mean by a smart building and how infrared detectors are being used to make building more intelligent. [Online]. Available: http://cdn2.hubspot.net/hub/13940/file257413033pdf/docs/Smart Buildings White Paper Aug 2013.pdf, (Accessed: 21 August, 2019).

Ilankoon, I.M.S.K. Ghorbani, Y., Chong, M.N., Herath, G., Moyo, T., and Petersen, J., (2018). waste in the international context - A review of trade flows, regulations, hazards, waste management strategies and technologies for value recovery. Waste Management, 82, pp. 258275, https://doi.org/10.1016/j.wasman.2018.10.018. 
Indrawati, Rosiana.Y. and Amani, H., (2017). Indicators to Measure a Smart Building: An Indonesian Perspective. International Journal of Computer Theory and Engineering, 9(6), http://www.ijcte.org/vol9/1176-IT0019.pdf, (Accessed: 23 August, 2019).

Iwaro, J. and Mwasha, A., (2010). A review of building energy regulation and policy for energy conservation in developing countries. Energy Policy, 38(12), pp.7744-7755, https://doi.org/10.1016/j.enpol.2010.08.027.

Karlessi, T., Kampelis, N., Kolokotsa, D., Santamouris, M., Standardi, L., Isidori, D. and Cristalli, C., (2017). The concept of smart and NZEB buildings and the integrated design approach. Procedia engineering, 180, pp. 1316-1325, https://doi.org/10.1016/j.proeng.2017.04.294.

Kline, R.B., (2011). Principles and practice of structural equation modelling (3rd ed.). Guilford publications, ftp://158.208.129.61/suzuki/PP_SEM_3e.pdf, Accessed: 05/06/2020.

Koranteng, C. and Mahdavi, A., (2011). An investigation into the thermal performance of office buildings in Ghana. Energy and Buildings, 43(2-3), pp.555-563, https://doi.org/10.1016/j.enbuild.2010.10.021.

Koranteng, C., (2010). Energy Performance of Office Buildings in Ghana. Journal of Science and Technology (Ghana), 30(2), https://doi.org/10.4314/just.v30i2.60542.

McGlinn, K., O'Neill, E., Gibney, A., O'Sullivan, D. and Lewis, D., (2010). SimCon: A Tool to Support Rapid Evaluation of Smart Building Application Design using Context Simulation and Virtual Reality. J. UCS, 16(15), pp.1992-2018, http://www.jucs.org/jucs_16_15/simcon_a_tool_to/jucs_16_15_1992_2018_mcglinn.pdf. Accessed: 05/06/2020.

Makarfi, Z., (2015), An Assessment of The Level of Awareness of Intelligent Buildings Amongst Nigerian Architects (A Case Study of Kaduna Metropolitan Area), Department of Architecture, Faculty of Environmental Design, Ahmadu Bello University, Zaria, Undergraduate Thesis, , Accessed:05/06/2020.

Mohamed, I.F., Edwards, D.J., Mateo-Garcia, M. Costin, G. and Thwala, W.D. (2020) Grenfell disaster: an investigation into the construction industry's view on the effect and aftermath of fire in high-rise buildings. International Journal of Building Pathology and Adaptation. DOI: https://doi.org/10.1108/IJBPA-05-2019-0048

Newman, C., Edwards, D.J., Martek, I., Lai, J. and Thwala, W.D. (2020) Industry 4.0 Deployment in the Construction Industry: A Bibliometric Literature Review and UK-based Case Study, Smart and Sustainable Built Environment DOI: https://doi.org/10.1108/SASBE-02-20200016

Nižetić, S., Djilali, N., Papadopoulos, A. and Rodrigues, J.J., (2019). Smart technologies for promotion of energy efficiency, utilization of sustainable resources and waste management. Journal of Cleaner Production, https://doi:10.1016/j.jclepro.2019.04.397.

Norušis, M.J., (2011). IBM SPSS statistics 19 guide to data analysis. Upper Saddle River, New Jersey: Prentice Hall, https://www.worldcat.org/title/ibm-spss-statistics-19-guide-to-dataanalysis/oclc/1014102959?referer=di\&ht=edition, Accessed: 05/06/2020.

Owusu-Manu, D., Pärn, E., Kutin-Mensah, E. K. and Edwards, D. J. (2018) Power infrastructure sector reforms, power generation and private investments: empirical evidence from Ghana's power sector. ASCE Journal of Infrastructure Systems, 24(3), pp. DOI: https://doi.org/10.1061/(ASCE)IS.1943-555X.0000423

Optergy (2019), Building Management System, https://optergy.com/applications/buildingmanagement-system/, Accessed: 10/09/2019.

Park, J.Y. and Nagy, Z., (2018). Comprehensive analysis of the relationship between thermal comfort and building control research-A data-driven literature review. Renewable and Sustainable Energy Reviews, 82, pp. 2664-2679, https://doi.org/10.1016/j.rser.2017.09.102.

Pärn, E. A. and Edwards, D. J. (2019) Cyber threats confronting the digital built environment: Common data environment vulnerabilities and block chain deterrence, Engineering, Construction and Architectural Management, 26(2), pp. 245-266. DOI: https://doi.org/10.1108/ECAM-03-2018-0101

Pedrasa M. A. A., (2010). Spooner TD, McGill IF. Coordinated scheduling of residential distributed energy resources to optimize smart home energy services. IEEE Trans Smart Grid; (1), pp. 134-43, https://ieeexplore.iee.org/abstract/document/5524053/. 
Peeples, D. (2016), Smart cities evolution: Is your city keeping up? Smart Cities Council, https://smartcitiescouncil.com/article/smart-cities-evolution-your-city-keeping, Accessed $12 / 11 / 2019$.

Raffetti, E., Treccani, M. and Donato, F., (2019). Cement plant emissions and health effects in the general population: a systematic review. Chemosphere, 218, pp. 211-222. https://doi.org/10.1016/j.chemosphere.2018.11.088.

Research Optimus (2020), What is Frequency Analysis? Research Optimum, https://www.researchoptimus.com/article/frequency-analysis.php, Accessed: 16/02/2020.

RevisionMaths (2019), Standard Deviation, https://revisionmaths.com/gcse-maths-revision/statisticshandling-data/standard-deviation, Accessed: 15/02/2020.

Rowlinson, S.M., (1988). An Analysis of Factors Affecting Project Performance in Industrial Building. Ph.D thesis, Brunel Univ., Middlesex, U.K, https://bura.brunel.ac.uk/bitstream/2438/4320/1/FulltextThesis.pdf, Accessed: 05/06/2020.

Runde, S. and Fay, A., (2011). Software support for building automation requirements engineeringAn application of semantic web technologies in automation, Transactions on Industrial Informatics, 7(4), pp.723-730, https://doi.org/10.1109/TII.2011.2166784.

Santamouris, M., (2016). Cooling the buildings-past, present and future. Energy and Buildings, 128, pp.617-638, https://doi.org/10.1016/j.enbuild.2016.07.034.

Santos, J.R.A., (1999). Cronbach's alpha: A tool for assessing the reliability of scales. Journal of extension, 37(2), pp.1-5. https://www.joe.org/joe/1999april/tt3.php, Accessed: 16/02/2020.

Sarfo, M., (2016), Contractor's adaptation to the environmentally sustainable construction process in Ghana, Department of Construction Technology and Management, Kwame Nkrumah University of Science and Technology, Doctoral Dissertation, http://ir.knust.edu.gh/bitstream/123456789/10456/1/Sarfo_Thesis_final\%20submission.pdf.

Shaikh, P.H., Nor, N.B.M., Nallagownden, P., Elamvazuthi, I. and Ibrahim, T., (2014). A review on optimized control systems for building energy and comfort management of smart sustainable buildings. Renewable and Sustainable Energy Reviews, 34, pp.409-429, https://doi.org/10.1016/j.rser.2014.03.027.

Sinopoli, J. (2010). Smart building systems for architects, owners and builders. Burlington (MA): Elsevier, https://doi.org/10.1016/B978-1-85617-653-8.00001-6.

Smart cities start with smart buildings. (2016). Harvard Business Review. [Online]. Available: https://hbr.org/sponsored/2016/01/smart-cities-start-with-smartbuildings, (Accessed: 12 August, 2019).

Stephanie (2014), Inferential Statistics: Definition, Uses, Statistics How To, https://www.statisticshowto.datasciencecentral.com/inferential-statistics/, $\quad$ Accessed: $15 / 02 / 2020$.

Stevens, J.P., (2012). Applied multivariate statistics for the social sciences. Routledge, https://books.google.com.gh/books?hl=en\&lr=\&id=oIeDhzDebKwC\&oi=fnd\&pg=PR1\&dq= Stevens,+J.P.,+(2012).+Applied+multivariate+statistics+for+the+social+sciences.+Routledge \&ots=1I5Hs9Czb8\&sig=mfEmBaozT8phHUmKLERVEIuzW8w\&redir_esc=y\#v=onepage \& $\mathrm{q} \& \mathrm{f}=$ false, Accessed:05/06/2020.

Supratman. (2016). Smart building solution for high rise building. The smart way for green building. [Online]. Available: https://kampiun.telkom.co.id/kampiun/kampiun/main.php, Accessed: 10/09/2019.

Tabachnick, B.G., and Fidell, L.S., (2001). Using multivariate statistics. Allyn \& 1205 Bacon, https://faculty.chass.ncsu.edu/garson/PA765/tabachnick.htm, Accessed: 05/06/2020.

Tan, W.C.K., (2011). Practical Research Methods, Pearson Custom, Singapore, https://www.amazon.com/Practical-Research-Methods-Third-Revised/dp/981068021X, Accessed: 05/06/2020.

Urge-Vorsatz, D., Petrichenko, K., Staniec, M. and Eom, J., (2013). Energy use in buildings in a longterm perspective. Current Opinion in Environmental Sustainability, 5(2), pp.141-151, https://doi.org/10.1016/j.cosust.2013.05.004.

Ürge-Vorsatz, D., Rosenzweig, C., Dawson, R.J., Rodriguez, R.S., Bai, X., Barau, A.S., Seto, K.C. and Dhakal, S., (2018). Locking in positive climate responses in cities. Nature Climate Change, 8(3), pp.174, https://doi.org/10.1038/s41558-018-0100-6. 
Vattano, S., (2014). Smart Buildings for A Sustainable Development. Journal of Economics World, 2 , pp.310-324, http://www.academia.edu/download/35920270/Economics_World_ISSN_23287144_Vol.2_No.5_2014.pdf\#page=25, Accessed: 05/06/2020.

Vázquez, J.L., Lanero, A., Gutiérrez, P. and Sahelices, C., (2018). The contribution of smart cities to quality of life from the view of citizens. In Entrepreneurial, Innovative and Sustainable Ecosystems, pp. 55-66. Springer, Cham, https://doi.org/10.1007/978-3-319-71014-3 3.

VITO NV (2018). Smart Readiness Indicator for Buildings. Available online: https://smartreadinessindicator.eu/. Accessed: 04/06/2020.

Wang, X., Yang, G., Feng, Y., Ren, G. and Han, X., (2012). Optimizing feeding composition and carbon-nitrogen ratios for improved methane yield during anaerobic co-digestion of dairy, chicken manure and wheat straw. Bioresource technology, 120, pp.78-83, https://doi.org/10.1016/j.biortech.2012.06.058.

Wang, X.C., Klemeš, J.J., Dong, X., Fan, W., Xu, Z., Wang, Y., Varbanov, P.S., (2019). Air pollution terrain nexus: A review considering energy generation and consumption. Renewable and Sustainable Energy Reviews, 105, pp. 71-85, https://doi.org/10.1016/j.rser.2019.01.049.

Witt, J. (2007), The Origin of Intelligent Design, Discovery Institute, https://www.discovery.org/a/3207/, Accessed 13/02/2020.

Wong, J., Li, H. and Lai, J. (2008), Evaluating the system intelligence of the intelligent building systems", Automation in Construction, 17 (3), pp. 284-302, https://doi.org/10.1016/j.autcon.2007.06.002.

World-GBC, (World Green Building Council) (2017), What is Green Building? http://www.worldgbc.org/index.php?cID=220, (Accessed: 24 August, 2019)

Wouters, P. and Laustsen, J., (2017). The smartness indicator. REHVA, 2, pp.19-22. Smart Cities Council, 2013, IDC: Top 10 smart cities predictions for 2013, https://smartcitiescouncil.com/article/idc-top-10-smart-cities-predictions-2013, Accessed: $10 / 09 / 2019$ 